\title{
Chemical, Physicochemical, Nutritional, Microbiological, Sensory and Rehydration Characteristics of Instant Whole Beans (Phaseolus vulgaris)
}

\author{
José Armando Ulloa 1,2,3*, Silvia Jazmin Ibarra-Zavala², Silvia Patricia Ramírez-Salas², \\ Petra Rosas-Ulloa ${ }^{1,2}$, José Carmen Ramírez-Ramírez ${ }^{4}$ and Blanca Estela Ulloa-Rangel ${ }^{2}$ \\ ${ }^{1}$ Center of Food Technology, Autonomous University of Nayarit, Ciudad de la Cultura Amado Nervo, \\ Tepic, CP 63155 Nayarit, Mexico \\ ${ }^{2}$ Academic Unit of Chemical Biology and Pharmaceutical Sciences, Autonomous University of Nayarit, \\ Ciudad de la Cultura Amado Nervo, Tepic, CP 63155 Nayarit, Mexico \\ ${ }^{3}$ Academic Unit of Agriculture, Autonomous University of Nayarit, Carretera Tepic-Puerto Vallarta, \\ Xalisco, CP 63780 Nayarit, Mexico \\ ${ }^{4}$ Academic Unit of Veterinary and Animal Science, Autonomous University of Nayarit, \\ Carretera a Chapalilla, Compostela, CP 63700 Nayarit, Mexico
}

Received: April 1, 2014

Accepted: January 9, 2015

\begin{abstract}
Summary
Instant whole beans obtained by drying at $25{ }^{\circ} \mathrm{C}$ were evaluated for their chemical, physicochemical, nutritional, microbiological, sensory and rehydration characteristics. The proximal composition of instant whole beans was typical of this kind of food, whereas $a_{\mathrm{w}}$ and $L^{*}, a^{*}$ and $b^{*}$ values were $0.639,98.55,-0.28$ and -1.52 , respectively. In instant whole beans, $75 \%$ of the essential amino acids had a value greater or equal to the reference standard for adult humans; the protein quality in terms of chemical score was $95 \%$. Microbiological counts of aerobic mesophilic bacteria, moulds, yeasts and total coliforms of rehydrated instant whole beans were $<10 \mathrm{CFU} / \mathrm{g}$, whereas the scores for colour, flavour, texture and overall acceptability were 7.22, 7.68, 7.24 and 7.34, respectively, on a 1-9 hedonic scale. The logarithmic and Pilosof models showed close fits $\left(R^{2}>0.99\right)$ to the experimental data for drying of cooked beans and rehydration of instant whole beans, respectively. In the light of the chemical, physicochemical, nutritional, microbiological, sensory and rehydration characteristics of instant whole beans found in this study, drying at $25^{\circ} \mathrm{C}$ is recommended for the production of such food.
\end{abstract}

Key words: instant whole beans, protein quality, sensory quality, rehydration

\section{Introduction}

Beans of Phaseolus vulgaris (common beans) are an important food crop both from the economic and nutritional points of view, and are cultivated and consumed worldwide (1). They are a rich source of proteins, complex carbohydrates, dietary fibres and minerals, but they also contain biologically active phytochemicals that are important for human health (2). Clinical studies have shown that regular consumption of beans helps to decrease colon cancer incidence and multiplicity, and it can prevent alterations in the gastrointestinal tract, cardiovascular disease and diabetes $(3,4)$.

The physiological effects of dry bean consumption may be due to the presence of abundant phytochemicals, 
including polyphenolics, which possess both anticarcinogenic and antioxidant properties (5). Compared to other carbohydrate sources, beans have a low glycemic index, so incorporation of this foodstuff into the diet may help control the blood glucose level in people with diabetes and other chronic degenerative diseases $(6,7)$.

Beans also contain several antinutritional factors such as inhibitors of trypsin, chymotrypsin, and amylase, as well as phytic acid, flatulence-producing oligosaccharides, saponins, and lectin, which interfere with the bioavailability of nutrients (8). However, the contents of all of these antinutritional factors can be reduced or eliminated by certain culinary practices such as discarding the soaking water before cooking or the use of a soaking solution of sodium bicarbonate or citric acid prior to cooking $(8,9)$.

The major obstacle in encouraging the use of dry beans is their tough seed coats and consequently the long cooking time needed to tenderize them. Thus, the development of value-added bean-based products as dehydrated precooked beans is now in high demand by the food industry, fast-food restaurants, and domestic consumers (10). Process conditions required for the production of dehydrated precooked beans of acceptable quality have been defined in previous studies. However, most methods are associated with problematic butterflying and splitting, which usually results in the loss of bean structure, flavour, texture and identity (11).

The high rate of drying of cooked beans causes seed coat splitting, which can be minimized by the use of low air velocity and low temperature during drying (11). Lowering the process temperature has great potential for improving the quality of dried products (12). Indeed, some studies have focused on the use of low drying air temperature and the impact it has on product quality (13).

Several changes of quality parameters occur during the drying process. The extent of changes depends both on the care taken in preparing the material before drying and on the process used. Major quality parameters associated with dried food products include sensory and rehydration properties, microbial load, retention of nutrients, and water activity amongst others (14). To our knowledge, there are no reports about the chemical, physicochemical, nutritional, microbiological, sensory and rehydration characteristics of instant whole beans produced by drying at room temperature. Therefore, the main aim of this research is to study the chemical, physicochemical, nutritional, microbiological, sensory and rehydration properties of instant whole beans (Phaseolus vulgaris) obtained by drying at room temperature.

\section{Materials and Methods}

\section{Raw material}

Bean (Phaseolus vulgaris L. var. Flor de Mayo) seeds harvested in November 2012 were purchased from the Mercado de Abastos, located at Tepic, Nayarit, Mexico. This bean variety is the second most commonly consumed in the West region of Mexico, and it is classified as medium size (between 25 and $40 \mathrm{~g}$ per $100 \mathrm{~g}$ of seeds). The chemicals were purchased from Sigma-Aldrich (Mex- ico, D.F., Mexico) and reagents and the amino acid standard from Waters (Mexico, D.F., Mexico). All chemicals used were of analytical grade and deionized water was used.

\section{Cooking beans}

Before cooking, the dry beans were sorted to remove broken, cracked, and damaged ones. Batches of $200 \mathrm{~g}$ were washed with tap water. Beans were blanched in tap water at bean per water ratio $1: 4$ and $95^{\circ} \mathrm{C}$ for $3 \mathrm{~min}$. After blanching, the beans were soaked in tap water at bean per water ratio $1: 7$ and $45^{\circ} \mathrm{C}$ for $120 \mathrm{~min}$, and then the hydrated beans were cooked in a pot at $97^{\circ} \mathrm{C}$ for $120 \mathrm{~min}$.

\section{Drying method}

The cooked beans were dried in a drying cabinet at room temperature $\left(25^{\circ} \mathrm{C}\right)$ under an air velocity of $(180 \pm 1)$ $\mathrm{m} / \mathrm{min}$ and relative humidity of $(55 \pm 5) \%$. In this dryer, air was flowing horizontally through cooked beans. The velocity of the air passing through the system was measured using a CEM DT-618 thermo-anemometer (Shenzhen Everbest Machinery Industry, Co., Ltd, Nanshan, Shenzhen, PR China). For drying, $400 \mathrm{~g}$ of precooked beans were uniformly spread in a single layer on a rectangular tray formed by an aluminium frame (size: $40 \mathrm{~cm} \times 30 \mathrm{~cm}$ ) and a plastic mesh where the distance between wires was 1.3 $\mathrm{mm}$. The samples of beans were removed from the dryer at 30-min intervals during the drying process, and their mass was recorded with a digital scale with $0.01 \mathrm{~g}$ accuracy (Ohaus Corporation, Parsippany, NJ, USA). Drying of the cooked beans continued until the decrease in mass was negligible, which was achieved at a final moisture content of $(1.46 \pm 0.09) \mathrm{g}$ of water per $100 \mathrm{~g}$ of dry matter. Three replicates of the drying experiment were carried out. The final moisture content was considered to be the value of equilibrium moisture content. Moisture ratio (MR) was calculated with the following equation:

$$
\mathrm{MR}=\frac{X-X_{\mathrm{e}}}{X_{0}-X_{\mathrm{e}}}
$$

where $X$ is the moisture content at any time ( $g$ of water per $g$ of dry solid), $X_{\mathrm{e}}$ is the equilibrium moisture content ( $g$ of water per $g$ of dry solid), and $X_{0}$ is the initial moisture content ( $g$ of water per $g$ of dry solid).

The experimental data obtained from drying study were fitted to the moisture ratio models detailed in Table $1(15,16)$, in order to determine the kinetic parameters of drying, and then define which one best describes drying behaviour.

\section{Chemical and physicochemical analyses}

Moisture, fat, protein $(\mathrm{N} \times 6.25)$, ash, and total carbohydrate contents were determined in triplicate using standard methods reported by AOAC (17). Water activity $\left(a_{\mathrm{w}}\right)$ was measured in triplicate at $25^{\circ} \mathrm{C}$ by using a Decagon Aqualab meter CX-2 (Pullman, WA, USA), on coarse powder samples ( $3 \mathrm{~g})$, which were obtained by grinding the precooked beans with a mortar and pestle. Prior to testing the samples, the water activity meter was turned on and allowed to warm up for $30 \mathrm{~min}$ and calibrated by filling half a plastic disposable cup with a saturated sodium 
Table 1. Mathematical models for fitting drying data $(15,16)$

\begin{tabular}{ll}
\hline Model & Model equation \\
\hline Henderson and Pabis & $\mathrm{MR}=a \cdot \mathrm{e}^{-\mathrm{k} \cdot \mathrm{t}}$ \\
Lewis & $\mathrm{MR}=\mathrm{e}^{-\mathrm{k} \cdot \mathrm{t}}$ \\
Logarithmic & $\mathrm{MR}=a \cdot \mathrm{e}^{-\mathrm{k} \cdot \mathrm{t}}+c$ \\
Midelli et al. & $\mathrm{MR}=a \cdot \mathrm{e}^{-\mathrm{k} \cdot \mathrm{t}}+b \cdot t$ \\
Modified Henderson and Pabis & $\mathrm{MR}=a \cdot \mathrm{e}^{-\mathrm{k} \cdot \mathrm{t}}+b \cdot e^{-\mathrm{g} \cdot \mathrm{t}}+c \cdot e^{-\mathrm{h} \cdot \mathrm{t}}$ \\
Modified Midelli et al. & $\mathrm{MR}=\mathrm{e}^{-\mathrm{k} \cdot \mathrm{t}}+b \cdot t$ \\
Page & $\mathrm{MR}=\mathrm{e}^{-\mathrm{k} \cdot \mathrm{t}^{\mathrm{n}}}$ \\
Two term & $\mathrm{MR}=a \cdot \mathrm{e}^{-\mathrm{k}_{\mathrm{r}} \cdot \mathrm{t}}+b \cdot \mathrm{e}^{-\mathrm{k} 2 \cdot \mathrm{t}}$ \\
Wang and Singh & $\mathrm{MR}=1+a \cdot t+b \cdot t^{2}$ \\
\hline
\end{tabular}

$\mathrm{MR}=$ moisture ratio; $a, b, c, n=$ drying coefficients; $k, k_{1}, k_{2}, g, h=$ drying constants, $t=$ time

chloride solution. The accuracy of water activity values was $( \pm 0.003)$. Colour was determined with a Minolta CR-300 colour meter (Minolta, Tokyo, Japan). The measured values were expressed according to the CIELAB colour scale: $L^{*}$ (lightness), $a^{*}$ (redness-greenness), and $b^{*}$ (yellowness-blueness). The $L^{*}, a^{*}$ and $b^{*}$ values of the white standard tile used as reference were 97.14, 0.19 and 1.84, respectively. The colour was measured directly on the surface of each bean in a sample of 10 precooked beans. Precooked whole beans were examined to establish if they had either a crack between the cotyledons or a transverse fissure in the seed coat $>2 \mathrm{~mm}$ wide. The beans with split seed coats or cracked cotyledons in triplicate samples were counted. The results are reported as the percentage of split beans. Butterflied beans were defined as those with two cotyledons separated by more than half of the length of the bean (16).

\section{Amino acid analyses and protein quality}

The hydrolysis and quantification of amino acids were performed according to the methods reported by Erkan et al. (18), using a Waters high-performance liquid chromatographic system (Milford, MA, USA) consisting of a system controller, auto injector, liquid chromatographic pump, fluorescence detector, and degasser. The tryptophan content was determined according to AOAC method (17). The quality of protein was estimated by determination of total amino acids, as well as the fraction of the exogenous amino acids (EAA). Amino acids were expressed on a protein basis, equivalent to $\mathrm{g}$ per $16 \mathrm{~g}$ of protein. The chemical score (CS) was calculated as per the procedure described previously by Sujak et al. (19) based on the comparison of the mass fraction of the amino acid having the shortest supply, $w\left(a_{\mathrm{i}}\right)$ (restrictive amino acid) with the mass fraction of this amino acid in the standard, $w\left(a_{\mathrm{s}}\right)$ :

$$
\mathrm{CS}=\left[\frac{w\left(a_{\mathrm{i}}\right)}{w\left(a_{\mathrm{s}}\right)}\right] \cdot 100
$$

We followed the recommendation of the $\mathrm{FAO} / \mathrm{WHO}$ for choosing the amino acid standards (20). The recommended intake of exogenous amino acids for adult humans was as follows (in $\mathrm{g}$ per $16 \mathrm{~g}$ of $\mathrm{N}$ ): lysine 5.5, methionine plus cysteine 3.5, threonine 4.0, isoleucine 4.0, tryptophan 1.0, valine 5.0, leucine 7.0 , histidine 0 , and phenylalanine plus tyrosine 6.0. The EAA were estimated according to Oser (21) in terms of geometric mean of mass fractions of participating exogenous amino acids, $a_{1}$ to $a_{n}$ compared to a mass fraction of corresponding standard, $a_{1 \mathrm{~s}}$ to $a_{\mathrm{ns}}($ in $\mathrm{g}$ per $16 \mathrm{~g}$ of $\mathrm{N}$ ):

$$
\mathrm{EAA}=\sqrt[10]{\frac{w\left(a_{1}\right)}{w\left(a_{1 \mathrm{~s}}\right)} \cdot 100 \ldots \ldots \frac{w\left(a_{\mathrm{n}}\right)}{\mathrm{w}\left(a_{\mathrm{ns}}\right)} \cdot 100}
$$

where $n$ is the number of participating amino acids, and $n s$ is the number of corresponding amino acids in the standard.

The essential amino acid index (EAAI) was calculated as follows:

$$
\mathrm{EAAI}=10^{\log \mathrm{EAA}}
$$

Protein efficiency ratio (PER) was estimated according to the Alsmeyer et al. (22) method using the following equation:

$$
\mathrm{PER}=-0.468+0.454 \cdot w(\mathrm{Leu})-0.105 \cdot w(\mathrm{Tyr})
$$

where $w$ (Leu) and $w$ (Tyr) are mass fractions of leucine and tyrosine, respectively, expressed in $\mathrm{g}$ per $16 \mathrm{~g}$ of $\mathrm{N}$.

\section{Microbiological analysis}

For microbiological analysis, $10 \mathrm{~g}$ of beans were homogenized with $90 \mathrm{~mL}$ of sterile buffered peptone water $(0.1 \%)$ in a Stomacher ${ }^{\circledR}$ Lab Blender (model 400, Seward, Worthing, UK) for $2 \mathrm{~min}$. Decimal dilutions were made in sterile peptone water $(0.1 \%)$ and bacteria were plated in duplicate onto the specific media. Total aerobic bacterial counts were determined on plate count agar at $37^{\circ} \mathrm{C}$ for $48 \mathrm{~h}$, yeast and moulds on malt extract agar at $25^{\circ} \mathrm{C}$ for 72 $\mathrm{h}$, and total coliforms on violet red bile agar at $35^{\circ} \mathrm{C}$ for $24 \mathrm{~h}$ (23). The counts were expressed as colony forming units (CFU) per gram. All the culture media used were from BD Difco (Becton, Dickinson and Co., Franklin Lakes, NJ, USA).

\section{Sensory evaluation}

Beans for the sensory analysis were prepared by adding $300 \mathrm{~g}$ of instant whole beans and $18 \mathrm{~g}$ of salt to $1.6 \mathrm{~L}$ of water at $95{ }^{\circ} \mathrm{C}$, and maintaining this temperature for 15 min. A 50-member consumer panel, comprised mostly of students from the Autonomous University of Nayarit (Mexico) evaluated the reconstituted instant whole bean. A sample of $10 \mathrm{~g}$ of reconstituted instant whole beans was presented to each member of the consumer panel. The panellists were asked to evaluate the sensory quality in terms of colour, texture, flavour and overall acceptability on a 1-9 hedonic scale, where a score of 1 indicated dislike extremely, 2 dislike very much, 3 dislike moderately, 4 dislike slightly, 5 neither like nor dislike, 6 like slightly, 7 like moderately, 8 like very much, and 9 like extremely (24). All evaluations were conducted at room temperature $\left(25^{\circ} \mathrm{C}\right)$ on the same day. A score of 5 was considered the limit of acceptability for all sensory attributes tested.

\section{Rehydration characteristics}

Water absorption of dried precooked beans was determined according to a modification of the method described by Abu-Ghannam and McKenna (25). A sample of 
30 beans (10 g, weighed exactly) was placed in a net basket and immersed into a 250-mL glass jar with lid containing $100 \mathrm{~mL}$ of distilled water, which was previously heated to the required soaking temperature $\left(40,60\right.$, or $\left.80^{\circ} \mathrm{C}\right)$ by placement in a water bath thermostatically controlled at the required temperature $\left( \pm 1^{\circ} \mathrm{C}\right)$. Water absorption was recorded on a digital scale (Ohaus Corporation) by measuring the increase in bean mass every 3 min until the difference between consecutive mass measurements was insignificant $((0.05 \pm 0.01) \mathrm{g})$; this was considered to represent the saturation moisture content. There was no correction for lost solids. After the specified soaking time, the beans were removed from the soaking solution, drained on a kitchen strainer for $0.5 \mathrm{~min}$, blotted with paper tissue, and weighed. The mass gain was measured, and the beans were returned to the soaking solution at the required temperature. All soaking tests were done in triplicate and a percentage of moisture in dry matter was recorded. The rehydration rate was calculated using the following equation:

$$
w_{\mathrm{w}}=\frac{m_{\mathrm{r}}-m_{\mathrm{d}}}{m_{\mathrm{d}}}
$$

where $w_{\mathrm{w}}$ is water gain (g of water per $\mathrm{g}$ of solid) at any time, $m_{\mathrm{r}}$ is rehydrated sample mass $(\mathrm{g})$ and $m_{\mathrm{d}}$ is initial mass of dry sample (g).

The experimental data were adjusted to the Pilosof's model (16) which is calculated as follows:

$$
w_{\mathrm{w}}=\frac{w_{\mathrm{weq}} \cdot t}{t_{1 / 2}+t}
$$

where $w_{\mathrm{w}}$ is water gain (g of water per $\mathrm{g}$ of solid) at any time, $w_{\text {weq }}$ is water gain (g of water per $g$ of solid) at equilibrium, $t$ is time (min), and $t_{1 / 2}$ is time needed to gain half of equilibrium value $\left(w_{\text {weq }} / 2\right)$.

The rehydration rate was derived by differentiation equation with respect to time:

$$
\frac{\mathrm{d} w_{\mathrm{w}}}{\mathrm{d} t}=\frac{1}{t_{1 / 2} \cdot w_{\text {weq }}} \cdot\left(w_{\text {weq }}-w_{\mathrm{w}}\right)^{2}
$$

to give a specific rate constant, $k_{\mathrm{r}}$ :

$$
k_{\mathrm{r}}=\left(w_{\mathrm{weq}} \cdot t_{1 / 2}\right)^{-1}
$$

To illustrate the effects of soaking temperature on $w_{w}$ the Arrhenius equation was applied. The Arrhenius law can be represented as follows:

$$
k_{\mathrm{r}}=k \cdot \exp \frac{E_{\mathrm{a}}}{R \cdot T}
$$

where $k_{\mathrm{r}}$ is the constant of rehydration rate $\left(\mathrm{min}^{-1}\right), k$ is pre-exponential factor having units equivalent to the rehydration constant, $E_{\mathrm{a}}$ is activation energy $(\mathrm{kJ} / \mathrm{mol}), R$ is universal gas constant $(0.8314 \mathrm{~kJ} / \mathrm{mol} \mathrm{K})$, and $T$ is temperature $\left({ }^{\circ} \mathrm{K}\right)$.

\section{Statistical analysis}

Fitting procedure and the drying and rehydration constants were obtained using least squares analysis by Solver in Microsoft Excel 2010 (Microsoft Corporation Inc., New York, NY, USA) (26). The coefficient of determination $\left(R^{2}\right)$, reduced chi-square $\left(\chi^{2}\right)$, and root mean square error (RMSE) were the three criteria of statistical analysis used to evaluate the adjustment of the experimental data from the drying and rehydration studies to the different models. Lower values of $\chi^{2}$ and RMSE, and higher value of $\mathrm{R}^{2}$ indicate better fitting (27). All experiments and analysis were conducted in triplicate, and data are expressed as the mean value \pm standard deviation (S.D.).

\section{Results and Discussion}

\section{Drying of cooked beans}

The initial moisture content of the cooked beans used in the dehydration experiment was $(1.839 \pm 0.027) \mathrm{g}$ of water per $g$ of dry matter. Moisture ratio (MR) as a function of dehydration time is shown in Fig. 1. It decreased with time to an asymptotic value of 0 in $23 \mathrm{~h}$. A drying study of cooked whole beans of the variety Canario at $25^{\circ} \mathrm{C}$ under an air velocity of $(180 \pm 1) \mathrm{m} / \mathrm{min}$ and relative humidity of

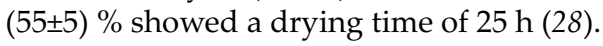

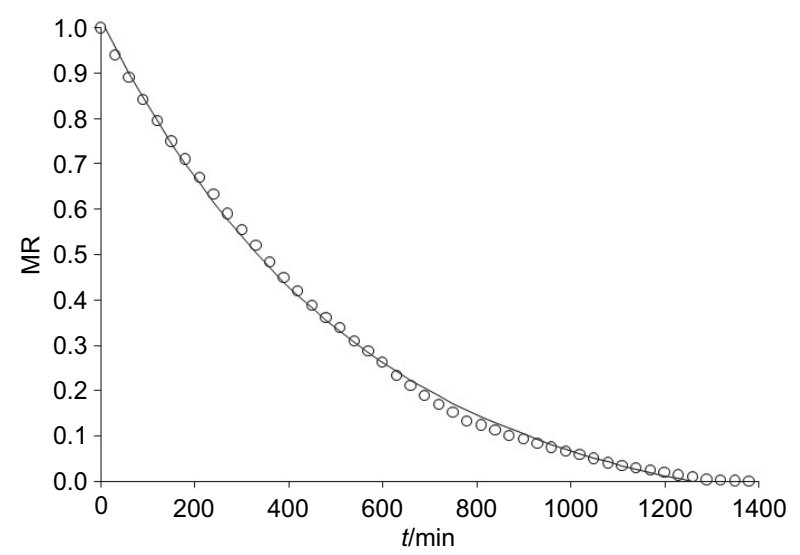

Fig. 1. Drying kinetics of cooked beans at room temperature $\left(25^{\circ} \mathrm{C}\right)$ : o, experimental data; - , logarithmic model; MR=moisture ratio

A close fit between the logarithmic semitheoretical model (Table 2) and the experimental data was obtained when the $k_{\mathrm{d}}$ value of $1.84 \cdot 10^{-3} \mathrm{~min}^{-1}(a=1.12960, c=-0.11122)$ was identified. This model showed the lowest values of $\chi^{2}$ and RMSE, as well as the highest value of $\mathrm{R}^{2}$ in comparison with the other tested models. The same model has been employed to describe the dehydration kinetic of apricots and sweet cherry (29), sweet pepper (30) and tomatoes (31). In recent years, microwave dehydration has gained popularity as an alternative dehydration method for a wide variety of food and agricultural products. Microwave treatment can greatly reduce the dehydration time of biological products without compromising their quality (32). Dehydration of cooked chickpeas and soya beans using a combination of microwave and air convection produced highly rehydratable products in short dehydration times (33). However, in the case of instant whole beans, a low dehydration rate is required to avoid or significantly reduce the incidence of splitting or butterflying, which was achieved with the dehydration conditions employed in this experiment. 
Table 2. Curve fitting criteria for the mathematical models $(15,16)$ and parameters of cooked beans dried at room temperature

\begin{tabular}{lllcc}
\hline Model name & Model constant & $\mathrm{R}^{2}$ & $\chi^{2}$ & \multicolumn{1}{c}{ RMSE } \\
\hline Henderson and Pabis & $a: 1.06141 ; k: 0.00241$ & 0.99284 & 0.001095 & 0.032389 \\
Lewis & $k: 0.00228$ & 0.99053 & 0.001417 & 0.037242 \\
Logarithmic & $a: 1.12960 ; k: 0.00184 ; c:-0.11122$ & 0.99896 & 0.000161 & 0.012292 \\
Midelli et al. & $a: 0.75583 ; k:-5.37 \cdot 10^{-3} ; b:-0.00066$ & 0.94655 & 0.008004 & 0.088513 \\
Modified Henderson and Pabis & $a: 0.35380 ; k: 0.00241 ; b: 0.35380 ; g: 0.00241 ; c: 0.35380 ; h: 0.00241$ & 0.99284 & 0.001202 & 0.032389 \\
Modified Midelli et al. & $k: 0.00195 ; b=-6.98 \cdot 10^{-5}$ & 0.99835 & 0.000251 & 0.015509 \\
Page & $k: 0.00052 ; n: 1.23406$ & 0.99828 & 0.000262 & 0.015860 \\
Two term & $a: 0.53070 ; k_{1}: 0.00241 ; b: 0.53070 ; k_{2}: 0.00241$ & 0.99284 & 0.001146 & 0.032389 \\
Wang and Singh & $a:-0.00164 ; b: 6.81 \cdot 10^{-7}$ & 0.99859 & 0.000215 & 0.014371 \\
\hline
\end{tabular}

$a, b, c, n=$ drying coefficients; $k, k_{1}, k_{2}, g, h=$ drying constants

\section{Chemical and physicochemical characteristics}

Table 3 shows the proximal composition and some physicochemical characteristics of instant whole beans. Other studies have reported similar values for moisture, protein, and $a_{\mathrm{w}}$ of ready-to-eat beans obtained by dehydration with air at $49-65{ }^{\circ} \mathrm{C}(11)$. The $a_{\mathrm{w}}$ observed for instant whole beans is below limiting level of this parameter to ensure microbial stability, because it is generally accepted that no microbial growth will occur at $a_{\mathrm{w}}<0.66$ (34). With respect to colour, according to the $L^{*}, a^{*}$ and $b^{*}$ values, the instant whole beans were coloured with slightly greenish and bluish hues, producing a light brown visual appearance, which is typical of cooked bean of light bean varieties. The most common factors that can affect the colour of foods during processing are pigment degradation, browning reactions, ascorbic acid oxidation, acidity, and the presence of copper and iron in the cooking medium (35). The decrease in redness and yellowness of legumes might be explained by the degradation of colour pigments during cooking, while the darkening process caused by the presence of metals during cooking might result in an increase in redness and yellowness (36). In this study, the decrease in yellowness of precooked bean could be due to the degradation of pigments during cooking.

Table 3. Proximal composition and physicochemical properties of instant whole beans

\begin{tabular}{lc}
\hline Characteristics & Value \\
\hline$w($ moisture $) /($ g per $100 \mathrm{~g})$ & $12.8 \pm 0.4$ \\
$w($ ash $) /($ g per $100 \mathrm{~g})$ & $1.95 \pm 0.07$ \\
$w($ protein)/(g per100 g) & $18.5 \pm 0.1$ \\
$w($ fat $) /($ g per $100 \mathrm{~g})$ & $3.2 \pm 0.1$ \\
$w($ total carbohydrates $) /($ g per $100 \mathrm{~g})$ & $63.6 \pm 0.2$ \\
$a_{\mathrm{w}}$ & $0.64 \pm 0.01$ \\
$L^{*}$ & $98.6 \pm 0.3$ \\
$a^{*}$ & $-0.3 \pm 0.1$ \\
$b^{*}$ & $-1.5 \pm 0.3$ \\
Splitting/\% & $1.2 \pm 0.1$ \\
\hline
\end{tabular}

$a_{\mathrm{w}}=$ water activity; values are means \pm standard deviation of triplicate analyses

\section{Composition of amino acids and nutritive value}

Table 4 shows the results of the amino acid profile and indicators of the nutritional value of instant whole beans. In the instant whole beans obtained in this study, $75 \%$ of the essential amino acids (lysine, threonine, isoleucine, valine, leucine, phenylalanine and tyrosine) had

Table 4. Composition of amino acids and nutritive quality of instant whole beans

\begin{tabular}{|c|c|c|}
\hline Parameter & $\begin{array}{c}\text { Instant whole } \\
\text { beans }\end{array}$ & $\begin{array}{l}\mathrm{FAO} / \mathrm{WHO} \\
\text { reference for } \\
\text { adults }(20)\end{array}$ \\
\hline \multicolumn{3}{|l|}{$w(\mathrm{EAA}) /(\mathrm{g}$ per $16 \mathrm{~g}$ of $\mathrm{N})$} \\
\hline Lysine & 9.19 & 5.5 \\
\hline Methionine+cystine & 3.33 & 3.5 \\
\hline Cystine & 1.96 & \\
\hline Threonine & 4.37 & 4.0 \\
\hline Isoleucine & 4.46 & 4.0 \\
\hline Tryptophan & 0.95 & 1.0 \\
\hline Valine & 5.16 & 5.0 \\
\hline Leucine & 7.76 & 7.0 \\
\hline Phenylalanine+tyrosine & 8.59 & 6.0 \\
\hline Tyrosine & 3.06 & \\
\hline \multicolumn{3}{|l|}{$w(\mathrm{NEAA}) /(\mathrm{g}$ per $16 \mathrm{~g}$ of $\mathrm{N})$} \\
\hline Arginine & 7.66 & \\
\hline Aspartic acid & 11.10 & \\
\hline Serine & 5.26 & \\
\hline Glutamic acid & 13.16 & \\
\hline Proline & 3.64 & \\
\hline Glycine & 3.72 & \\
\hline Alanine & 3.74 & \\
\hline Histidine & 3.48 & \\
\hline$\Sigma($ EAA $) /($ g per $16 \mathrm{~g}$ of $\mathrm{N})$ & 43.81 & \\
\hline$\Sigma($ EAA $) /($ g per $16 \mathrm{~g}$ of $\mathrm{N})$ & 51.76 & \\
\hline CS & 95.00 & \\
\hline EAAI & 114.78 & \\
\hline PER & 2.73 & \\
\hline
\end{tabular}

EAA=essential amino acids, NEAA=non-essential amino acids, $\mathrm{CS}=$ chemical score, $\mathrm{EAAI}=$ essential amino acid index, $\mathrm{PER}=$ protein efficiency ratio 
a value greater or equal to the reference standard for adults (20), while the tryptophan and sulphur-containing amino acids (methionine and cysteine) were the limiting amino acids, as it has been observed in other bean varieties and legume seed protein isolates $(37,38)$. In contrast, the protein quality of instant whole beans in terms of chemical score was $95 \%$, in comparison with the values of $80-82 \%$ reported for other varieties of cooked beans $(37,39)$, while the essential amino acid index was $104.1 \%$, indicating a high nutritive value of the protein but lower than the reported values of $112-115 \%$ for raw and processed French beans (40). The protein efficiency ratio of the instant whole beans calculated from the regression equation of Alsmeyer et al. (22) had a value of 2.3. According to AOAC (17), the protein efficiency ratio is the ratio of the mass gain and the protein consumed, where casein is the reference protein in the assay. Therefore, the protein efficiency ratio of casein from the Alsemeyer et al. (22) equation can be extrapolated to estimate the relative nutritive quality of another protein. According to Li et al. (41) the contents of leucine and tyrosine of casein were 8.82 and $5.06 \mathrm{~g}$ per $16 \mathrm{~g}$ of $\mathrm{N}$, respectively. Therefore, the protein efficiency ratio of this protein extrapolated from the Alsmeyer et al. (22) equation is 3.0, and the relative protein efficiency ratio of instant whole beans to casein is $76.6 \%$.

\section{Microbiological characteristics}

Results of the microbiological counts of instant whole beans are shown in Table 5. Microbiological counts of moulds, yeasts and total coliforms of instant whole beans and the rehydrated product were undetectable under the conditions applied for sensory evaluation $\left(95^{\circ} \mathrm{C}\right.$ for 15 $\mathrm{min})$. In the case of aerobic mesophilic bacteria, the instant whole beans showed a count of $8.6 \cdot 10^{2} \mathrm{CFU} / \mathrm{g}$, which was eliminated with the rehydration procedure. The acceptable microbiological quality of the dried food varies widely depending on the type of food and microbial group. In the case of dried food-grade gelatin, dehydrated space food, and processed spices, the limits of the aerobic mesophilic bacteria counts are $10^{3}, 10^{4}$ and $10^{6} \mathrm{CFU} / \mathrm{g}$, respectively (42). In contrast, the safety limit for total coliforms in dehydrated egg products, dry milk powder, and dehydrated products (which require heating before consumption) are $10^{3}, 10^{2}$ and $10^{2} \mathrm{CFU} / \mathrm{g}$, respectively (43). Therefore, instant whole beans from this study had better microbiological characteristics compared with the abovementioned foods.

Table 5. Microbial counts (CFU/g) of instant whole beans and the rehydrated product

\begin{tabular}{lcccc}
\hline & $\begin{array}{c}\text { Aerobic } \\
\text { mesophilic } \\
\text { pacteria }\end{array}$ & Moulds & Yeast & $\begin{array}{c}\text { Total } \\
\text { coliforms }\end{array}$ \\
\hline $\begin{array}{l}\text { Instant whole beans } \\
\begin{array}{l}\text { Rehydrated instant } \\
\text { whole beans* }\end{array}\end{array}$ & $<10$ & $<10$ & $<10$ & $<10$ \\
\hline
\end{tabular}

*at $95^{\circ} \mathrm{C}$ in water for $15 \mathrm{~min}$

\section{Sensory quality}

Considering ready-to-eat products that require rehydration, the importance of sensory quality comes into play (44). Characteristics such as seed size, colour, shape, textural properties and cooked-bean flavours greatly affect the consumers' acceptance (45). The results of sensory evaluation of instant whole beans are presented in Fig. 2. The average scores for colour, flavour, texture, and overall acceptability were 7.22, 7.68, 7.24, and 7.34, respectively. None of the four evaluated attributes scored lower than 5, a score that is considered the limit of acceptability (46). Therefore, we conclude that instant whole beans are considered acceptable by consumers.

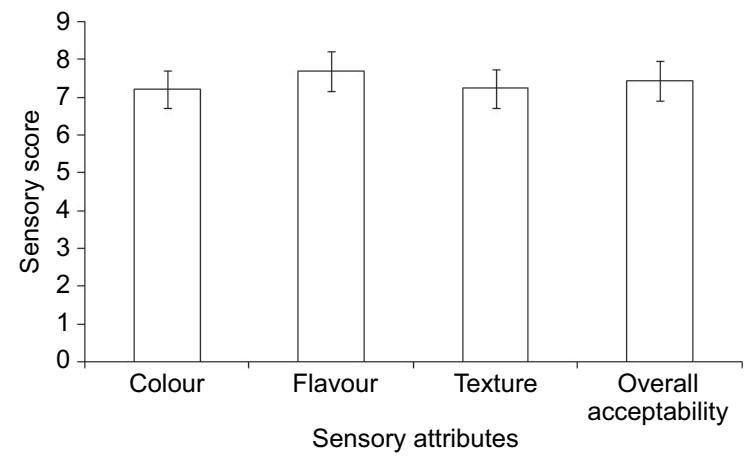

Fig. 2. Sensory scores of rehydrated instant whole beans

\section{Rehydration of instant whole beans}

A good fit was obtained when the experimental data were fitted to the Pilosof's model (16, Eq. 7). As shown in Fig. 3, water absorption curves of instant whole beans exhibited an initial high rate of rehydration followed by progressively lower uptake rates at later stages. The rapid initial water uptake by legumes is attributed to the filling of capillaries on the surface of the seed coats and at the hilum (47). The decline in rehydration rates at later stages is related to the combined effects of increased extraction rates of soluble materials and lower water absorption, presumably because of the filling of free capillaries and intermicellar spaces with water (48). Subsequently, amounts of water absorbed with further soaking were minimal until equilibrium was attained, which signalled the maxi-

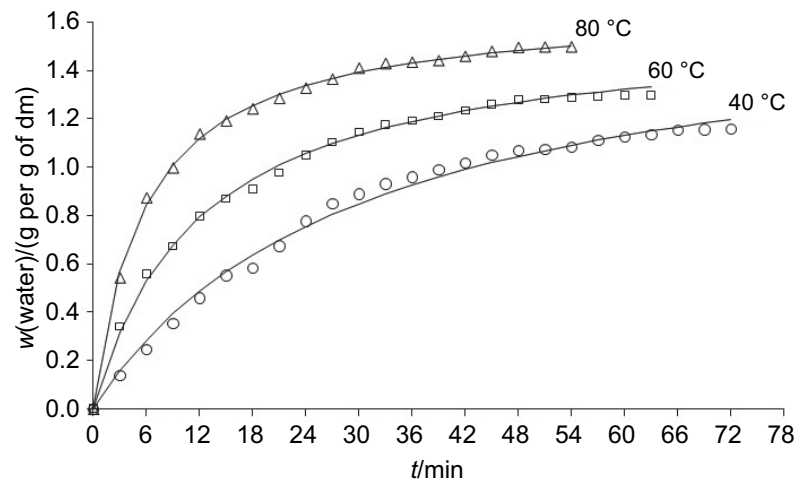

Fig. 3. Effect of temperature on rehydration of instant whole beans $(\mathrm{O}, \square, \Delta$, experimental data;,- Pilosof's model $(16)) ; \mathrm{dm}=$ dry matter 
Table 6. Rehydration characteristics of cooked beans dried at room temperature and then soaked at different temperatures

\begin{tabular}{|c|c|c|c|c|c|c|}
\hline$\frac{t \text { (soaking) }}{{ }^{\circ} \mathrm{C}}$ & $\frac{k_{\mathrm{r}}}{\min }$ & $\frac{w_{\text {weq }}}{\text { g per g of dm }}$ & $\begin{array}{l}\text { Regression equation of } \\
\text { rehydration rate }\end{array}$ & $\chi^{2}$ & RMSE & $\mathrm{R}^{2}$ \\
\hline 40 & $19.62 \cdot 10^{-3} \pm 2.94 \cdot 10^{-4}$ & $1.154 \pm 0.011$ & $\mathrm{~d} w_{\mathrm{W}} / \mathrm{d} t=50.96 \cdot w^{2}-58.86 \cdot w+69.91$ & 0.000876 & 0.028398 & 0.99309 \\
\hline 60 & $5.24 \cdot 10^{-2} \pm 6.80 \cdot 10^{-4}$ & $1.300 \pm 0.013$ & $\mathrm{~d} w_{\mathrm{W}} / \mathrm{d} t=19.07 \cdot w^{2}-51.30 \cdot w+32.23$ & 0.000345 & 0.017730 & 0.99731 \\
\hline 80 & $10.19 \cdot 10^{-2} \pm 1.12 \cdot 10^{-3}$ & $1.494 \pm 0.014$ & $\mathrm{~d} w_{\mathrm{W}} / \mathrm{d} t=9.80 \cdot w^{2}-29.29 \cdot w+21.88$ & 0.000173 & 0.012516 & 0.99877 \\
\hline
\end{tabular}

$k_{\mathrm{r}}=$ rehydration rate constant, $w_{\text {weq }}=$ equilibrium moisture content, $\chi^{2}=$ reduced chi-square, $\mathrm{RMSE}=$ root mean square error, $\mathrm{R}^{2}=$ coefficient of determination, $\mathrm{dm}=\mathrm{dry}$ matter. Results for $k_{\mathrm{r}}$ and $w_{\text {weq }}$ are expressed as mean values \pm standard deviations $(N=3)$

mum water capacity of instant whole beans, as has been observed for red kidney beans (25). Similar rehydration patterns for a variety of legumes had been reported previously $(49,50)$.

The $k_{\mathrm{r}}$ values of instant whole beans at different soaking temperatures obtained from Eq. 10, as well as the empirical rehydration equations related to the rate of moisture absorption are shown in Table 6. In general, increasing the soaking temperature resulted in an increase in both $k_{\mathrm{r}}$ and in the equilibrium moisture content. Increasing the soaking temperature from 40 to $60{ }^{\circ} \mathrm{C}$ increased $k_{\mathrm{r}}$ by 2.67 -fold, but a further increase from 60 to 80 ${ }^{\circ} \mathrm{C}$ resulted only in 1.94-fold elevated $k_{\mathrm{r}}$.

The rehydration characteristics of a dehydrated product can be used as a quality index. Such characteristics reflect the physical and chemical changes that occurred during dehydration, and these changes, in turn, are influenced by the composition of the samples, the conditions during drying, and by any pretreatment to which the products have been subjected (51). The amount and rate of absorbed water determine the sensorial properties and the preparation time required by the consumer. During rehydration, volume changes in biological materials are often proportional to the amount of absorbed water: the increase in volume because of water absorption equals the volume of imbibed water. Some research shows that the rehydration temperature markedly affects the increase in volume; moisture content (during processing time) increases with an increase in temperature, as was observed in the present study for instant whole bean. This trend has been observed for temperatures in the range of $40-80{ }^{\circ} \mathrm{C}$ for many fruits and vegetables (52).

The values of $\ln k_{\mathrm{r}}$ plotted $v s$. the reciprocal temperature values for instant whole beans are shown in Fig. 4.

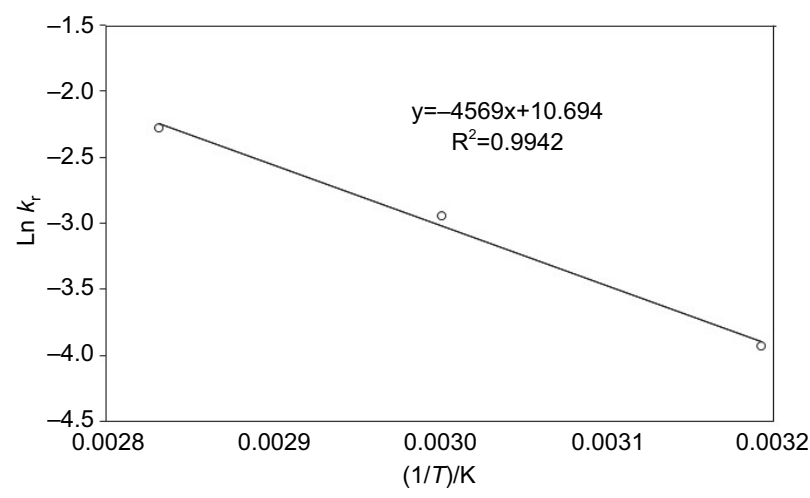

Fig. 4. Arrhenius plot of rehydration rate constant $v$ s. reciprocal temperature $(\mathrm{K})$ for instant whole beans
The high value of $\mathrm{R}^{2}$ confirmed that the water absorption rate of instant whole beans during soaking was temperature-dependent. The slope of the resulting straight line was used to calculate an $E_{\mathrm{a}}$ of $37.96 \mathrm{~kJ} /(\mathrm{mol} \cdot \mathrm{K})$, which is within the range of values reported for foods (27). According to the results of a study of hydration of red kidney beans, the $E_{\mathrm{a}}$ of blanched beans was $27.11 \mathrm{~kJ} /(\mathrm{mol} \cdot \mathrm{K})$ (25), which shows less sensitivity of the diffusivity against temperature than the instant whole beans in this study, because a greater value of $E_{\mathrm{a}}$ means higher sensibility of the diffusivity to temperature (27).

\section{Conclusions}

Drying at room temperature for obtaining instant whole beans generated a product of acceptable quality in the light of its chemical, physicochemical, nutritional, microbiological, sensory and rehydration characteristics. Because of the nutritional and health-promoting properties of dry beans, instant whole beans obtained by drying at room temperature could represent a good quality beanbased product for new market opportunities in the functional food and nutraceutical industry.

\section{Acknowledgements}

The authors wish to thank Promep-SEP-México for providing funds to support this research through grant 2649-UANCA-6.

\section{References}

1. Shilelis EA, Rakshit SK. Effect of processing on antinutrients and in vitro protein digestibility of kidney bean (Phaseolus vulgaris L.) varieties grown in East Africa. Food Chem. 2007; 103:161-72.

http://dx.doi.org/10.1016/j.foodchem.2006.08.005

2. Rochfort S, Panozzo J. Phytochemicals for health, the role of pulses. J Agric Food Chem. 2007;55:7981-94. http://dx.doi.org/10.1021/jf071704w

3. Reynoso-Camacho R, Rios-Ugalde MC, Torres-Pacheco I, Acosta-Gallegos A, Palomino-Salinas Ramos-Gómez CM, et al. The consumption of common bean (Phaseolus vulgaris L.) and its effect on colon cancer is Sprague Dawley rats. Agric Técnica. 2007;33:43-52 (in Spanish).

4. Bazzano IA, He J, Ogden I, Loria C, Vupputuri S, Myers I, et al. Legume consumption and risk of coronary heart disease in USA men and women. Arch Intern Med. 2001;161:2573-8. http://dx.doi.org/10.1001/archinte.161.21.2573

5. Cardador-Martínez A, Loarca-Piña G, Oomah BD. Antioxidant activity in common bean (Phaseolus vulgaris L.). J Ag- 
ric Food Chem. 2002;50:6975-80.

http://dx.doi.org/10.1021/jf020296n

6. Atkinson FS, Foster-Powell K, Brand-Miller JC. International tables of glycemic index and glycemic load values: 2008. Diabetes Care. 2008;31:2281-3. http://dx.doi.org/10.2337/dc08-1239

7. Silva-Cristobal L, Osorio-Díaz P, Tovar J, Bello-Pérez LA. Chemical composition, carbohydrate digestibility, and antioxidant capacity of cooked black bean, chickpea, and lentil Mexican varieties. Cyta-J Food 2010;8:7-14. http://dx.doi.org/10.1080/19476330903119218

8. Chau CF, Cheung PC, Wong YS. Effect of cooking on content of amino acids and antinutrients in three Chinese indigenous legume seeds. J Sci Food Agr. 1997;75:447-52. http://dx.doi.org/10.1002/(SICI)1097-0010(199712)75:4<447:: AID-JSFA896>3.0.CO;2-5

9. Yazmin A, Zeb A, Khalil AW, Paracha GM-U, Khattak AB. Effect of processing on anti-nutritional factors of red kidney bean (Phaseolus vulgaris) grains. Food Bioprocess Tech. 2008; 1:415-9. http://dx.doi.org/10.1007/s11947-008-0125-3

10. Wang N, Daun JK. Determination of cooking times of pulses using an automated Mattson cooker apparatus. J Sci Food Agric. 2005;85:1631-5. http://dx.doi.org/10.1002/jsfa.2134

11. Cai TD, Chang KC. Processing to improve quality of dehydrated precooked pinto beans. J Food Sci. 1997;62:141-4. http://dx.doi.org/10.1111/j.1365-2621.1997.tb04386.x

12. Beaudry C, Raghavan GSV, Ratti C, Rennie TJ. Effect of four drying methods on the quality of osmotically dehydrated cranberries, Dry Technol. 2004;22:521-39. http://dx.doi.org/10.1081/DRT-120029999

13. Ondier GO, Siebenmorgen TJ, Mauromoustakos A. Lowtemperature, low-relative humidity drying of rough rice. J Food Eng. 2010;100:545-50. http://dx.doi.org/10.1016/j.jfoodeng.2010.05.004

14. Ratti C. Freeze drying of plant products: where we are and where we are heading to. Stewart Postharv Rev. 2005;1:5-12. http://dx.doi.org/10.2212/spr.2005.4.5

15. McMinn WAM, Loughlin CM, Magee TRA. Thin-layer modeling of microwave-convective and microwave-vacuum drying of pharmaceutical powders. Dry Technol. 2005;23:51332 http://dx.doi.org/10.1081/DRT-200054126

16. García SV, Brumovsky LA, Fretes RM, Schmalko ME. Influence of drying temperature on the physical and microbiological parameters and the quality of dried green onion. Dry Technol. 2010;28:1435-44 http://dx.doi.org/10.1080/07373937.2010.482685

17. Cunniff $P$, editor. Official Methods of Analysis of AOAC International. Arlington, VA, USA: AOAC Publications; 1995.

18. Erkan N, Selçuk A, Özden O. Amino acid and vitamin composition of raw and cooked horse mackerel. Food Anal Methods. 2010;3:269-75. http://dx.doi.org/10.1007/s12161-009-9108-x

19. Sujak A, Kotlarz A, Strobel W. Compositional and nutritional evaluation of several lupin seeds. Food Chem. 2006;98:711-9. http://dx.doi.org/10.1016/j.foodchem.2005.06.036

20. Protein Quality Evaluation. Report of a joint FAO-WHO expert consultation. FAO Food and Nutrition Paper 51. Rome, Italy: FAO Publications; 1991.

21. Oser BL. An integrated essential amino acid index for predicting biological value of proteins. In: Albanese AA, editor. Protein and amino acid nutrition. New York, NY, USA: Academic Press; 1959. pp. 295-311.

22. Alsmeyer RH, Cunningham AE, Happich ML. Equations predict PER from amino acid analysis. Food Technol. 1974; 28:34-40.
23. Downes FP, Ito K, editors. Compendium of methods for the microbiological examination of foods. Washington DC, USA: APHA Publications; 2001.

http://dx.doi.org/10.2105/9780875531755

24. Amerine MA, Pangborn RM, Roessler BE. Principles of sensory evaluation of food. New York, USA: Academic Press; 1965.

25. Abu-Ghannam N, McKenna B. Hydration kinetics of red kidney beans (Phaseolus vulgaris L.). J Food Sci. 1997;62:520-3. http://dx.doi.org/10.1111/j.1365-2621.1997.tb04420.x

26. Phomkong W, Soponronnarit S, Thammarutwasik P. Chemical pretreatments affecting drying characteristics of chilli (cv. Huarou yon). Dry Technol. 2010;28:1466-76. http://dx.doi.org/ 10.1080/07373937.2010.482684

27. Erbay Z, Icier F. A review of thin layer drying of foods: Theory, modeling, and experimental results. Crit Rev Food Sci. 2010;50:441-64. http://dx.doi.org/10.1111/j.1365-2621.2009.02133.x

28. Ulloa JA, Bonilla-Sanchez CR, Ortíz-Jiménez MA, RosasUlloa P, Ramírez-Ramírez JC, Ulloa-Rangel BE. Rehydration properties of precooked whole bean (Phaseolus vulgaris) dehydrated at room temperature. Cyta-J Food 2013;11:94-9. http://dx.doi.org/10.1080/19476337.2012.699104

29. Doymaz I, Ismail O. Drying characteristics of sweet cherry. Food Bioprod Process. 2011;89:31-3. http://dx.doi.org/10.1016/j.fbp.2010.03.006

30. Vengaiah PC, Pandey JP. Dehydration kinetics of sweet pepper (Capsicum annum L). J Food Eng. 2007;81:282-6. http://dx.doi.org/10.1016/j.jfoodeng.2006.04.053

31. Khazaei J, Chegini GR, Bakhshiani M. A novel alternative method for modeling the effects of air temperature and slice thickness on quality and drying kinetics of tomato slices: superposition technique. Dry Technol. 2009;26:759-75. http://dx.doi.org/10.1080/07373930802046427

32. Mujumdar AS, Law CL. Drying technology: trends and applications in postharvest processing. Food Bioprocess Tech. 2010;3:843-52. http://dx.doi.org/10.1007/s11947-010-0353-1

33. Gowen AA, Abu-Ghannam N, Frias J, Oliveira J. Modeling dehydration and rehydration of cooked soybeans subjected to combined microwave-hot-air drying. Innov Food Sci Emerg Technol. 2008;9:129-37. http://dx.doi.org/10.1016/j.tifs.2005.11.013

34. Ross YH. Water activity and plasticization. In: Eskin NAM, Robinson DS, editors. Food shelf life stability. Chemical, biochemical and microbiological changes. Boca Raton, FL, USA: CRC Press LLC; 2001. pp. 13-36.

35. Bayram M, Oner MD, Kaya A. A Influence of soaking on the dimensions and colour of soybean for bulgur production. J Food Eng. 2004;61:331-9.

http://dx.doi.org/10.1016/S0260-8774(03)00137-7

36. Guzel D, Sayar S. Effect of cooking methods on selected physicochemical and nutritional properties of barlotto bean chickpea, faba bean, and white kidney bean. J Food Sci Technol. 2012;49:89-95. http://dx.doi.org/10.1007/s13197-011-0260-0

37. Słupski J. Evaluation of the amino acid content and sensory value of flageolet bean seeds (Phaseolus vulgaris L.) as affected by reprocessing methods before freezing. Int J Food Sci Technol. 2010;45:1068-75. http://dx.doi.org/10.1111/j.1365-2621.2010.02240.x

38. Kudre TG, Benjakula S, Kishimura H. Comparative study on chemical compositions and properties of protein isolates from mung bean, black bean and bambara groundnut. J Sci Food Agr. 2013;93:2429-36. http://dx.doi.org/10.1002/jsfa.6052 
39. Morales de León J, Bourges H, Camacho ME. Amino acid composition of some Mexican foods. Arch Lat Nutr. 2005; 55:172-86.

40. Kmiecik W, Lisiewska Z, Słupski J, Gebczynski P. Effect of preliminary and culinary processing on amino acid content and protein quality in frozen French beans. Int J Food Sci Technol. 2008;43:1786-91. http://dx.doi.org/10.1111/j.1365-2621.2007.01702.x

41. Li X, Rezaei R, Li P, Wu G. Composition of amino acids in feed ingredients for animal diets. Amino Acids 2011;40:1159-68. http://dx.doi.org/10.1007/s00726-010-0740-y

42. Jay JM, Loessner MJ, Golden DA. Miscellaneous food products. In: Modern food microbiology. New York, NY, USA: Springer Science+Business Media, Inc; 2005a. pp. 197-211.

43. Jay JM, Loessner MJ, Golden DA. Indicators of food microbial quality and safety. In: Modern food microbiology. New York, NY, USA: Springer Science+Business Media, Inc: 2005b. pp. 473-94.

44. Lewicki PP. Design of hot air drying for better foods. Trends Food Sci Tech. 2006;17:153-63. http://dx.doi.org/10.1016/j.tifs.2005.10.012

45. Mkanda AV, Minnar A, Kock DE. Relations consumer performance to sensory and physicochemical properties of dry beans (Phaseolus vulgaris L.). J Sci Food Agr. 2007;87:286879.

http://dx.doi.org/10.1002/jsfa.3046
46. Nyombaire G, Siddiq M, Dolan KD. Physico-chemical and sensory quality of extruded light red kidney bean (Phaseolus vulgaris L.) porridge, LTW-Food Sci. Technol. 2011;44: 1597-602. http://dx.doi.org/10.1016/j.lwt.2011.02.016

47. Hsu KH, Kim CJ, Wilson LA. Factors affecting water uptake of soybeans during soaking. Cereal Chem. 1983;60:208-11.

48. Plhak LC, Caldwell KB, Stanley DW. Comparison of methods used to characterize water imbibitions in hard-to-cook beans. J Food Sci. 1989;54:326-9.

http://dx.doi.org/10.1111/j.1365-2621.1989.tb03073.x

49. Berrios JDJ, Barry GS, Cheong WA. Physicochemical characterization of stored black beans (Phaseolus vulgaris L.). Food Res Int. 1999;32:669-76.

http://dx.doi.org/10.1016/S0963-9969(99)00144-1

50. Yildirim A, Oner MD, Bayram M. Modeling of water absorption of ultrasound applied chickpeas (Cicer arietinum L.) using Peleg's equation. J Agr Sci. 2010;16:278-86.

51. Maskan M. Drying, shrinkage and rehydration characteristics of kiwifruits during hot air and microwave drying. J Food Eng. 2001;48:177-82. http://dx.doi.org/10.1016/S0260 8774(00)00155-2

52. Krokida MK, Marinos-Kouris D. Rehydration kinetics of dehydrated products. J Food Eng. 2003;57:1-7. http://dx.doi.org/10.1016/S0260-8774(02)00214-5 